\title{
EXPERIENȚA LITURGICĂ A TĂCERII ÎN BISERICĂ. PARADIGMA SÂMBETEI MARI PENTRU POSTMODERNITATE.
}

Florin Parasca*

\begin{abstract}
Silence in the Church's liturgical experience. Holy Saturday paradigm for postmodernity. This study aims to present the liturgical experience of silence in the Church, through a parallel between the two meanings of preserving a moment of silence in worship, namely, that experienced by the Orthodox believers into the Presanctified Mass and that existing in Roman Catholic practice, especially after the Second Vatican Council, the "sacred silence". Seen more as an active liturgical participation of the faithful in adoration of Jesus, liturgical silence turns in Eastern Church in to the black coat of deep repentance, and hence, of the abnegation before supreme act of Giving Christ in the Eucharistic Sacrifice. That idea is captured admirably in Holy Saturday Cherubic (Tropar, voice 5), calling for silence the whole body because Savior comes, He kills Himself and give Himself food to all believers. For the nowadays man, here is the key for resolving the spiritual crisis: understanding and imitating Christ. He, as our God Creator, $\mathrm{He}$ sacrifices Himself for us to live; He gives Himself food, so as the man could have life, and even an abundant one (cf Jn. 10, 10). So Christ considered releasing mankind from the bondage of death: devoting Himself. At this supreme gesture of dedication from God, postmodern world is called that by silence and Eucharistic Communion, to revitalize the priorities.
\end{abstract}

Keywords: liturgical silence, Presanctified Mass, repentance, Holy Saturday, Eucharistic Communion, postmodernity, spiritual crisis

* PhD Candidate, „Andrei Şaguna University”, Sibiu, Romania. 
În cultul creştin, deopotrivă răsăritean şi apusean, există un element liturgic mai puțin supus atenției noastre, dar care defineşte, sau mai bine spus, încadrează exact raportul dintre noi şi Hristos. Acest element este tăcerea, adică întreruperea cântării şi a rugăciunilor, şi instaurarea unui moment de linişte totală în spațiul eclezial.

Poate din obişnuinţa cu care, angrenat în cotidian, este tot mai mult îndemnat să survoleze, ori poate din lipsa unei atente şi constante catehizări, creştinul de astăzi scapă cu uşurătate din vedere sensuri şi taine care-i marchează existenţa şi-i definesc devenirea. Astfel, chemarea Bisericii la liniştire, la reculegere, la meditare ori chiar la tăcere, nu mai este percepută în adevăratul ei sens, şi este chiar ignorată, atât timp cât mijloacele mass-media sau chiar unele destinații exotice oferă imediat confortul dorit, atât pentru organism, cât mai ales, pentru psihic.

În acest sens, secularismul, spunea Părintele Alexander Schmemann, are o consecință fatală pentru creştinism, care constă în aceea că neagă dimensiunea cultică a omului, şi prin urmare, acesta nu se mai recunoaşte pe sine ca fiind homo adorans, pentru care cultul era acel modus vivendi care îi împlinea umanitatea. Astfel, Părintele spune: „Secularismul nu admite ca ontologic şi epistemiologic «decisive» cuvintele care «întotdeauna, pretutindeni şi pentru toți» au constituit adevărata «epifanie» a relației omului cu Dumnezeu, cu lumea şi cu sine însuşi: «cu vrednicie şi cu dreptate este a-Ți cânta Ție, pe Tine a Te binecuvânta, pe Tine a Te lăuda, Ție a-Ți mulțumi, Ție a ne închina, în tot locul stăpânirii Tale...»" ". În plus, ideologia postmodernistă vine şi înlocuieşte chiar şi ultima urmă de sacralitate din sufletul uman cu propriile concepte şi viziuni asupra existenței, promovând subtil şi aproape insesizabil tolerarea şi alterarea noțiunii de păcat, disprețul față de Opera şi Providența divine, ignorarea cunoaşterii sensului creştin al vieții, egocentrismul,

\footnotetext{
${ }^{1}$ Preotul Profesor Alexander Schmemann, Pentru viața lumii. Sfintele Taine şi Ortodoxia, Bucureşti, Edit. Basilica, 2012, p. 149
} 
etica pluralist-relativistă, idolatria trupului, globalizarea gustului erotic, erotizarea iubirii şi liberalizarea sexuală² .

Astfel, în deruta şi vacarmul acestei lumi sufocate din ce în ce mai mult de secularism şi de moarte spirituală, ,prima grijă a Bisericii, spune Părintele Ioan Bizău, este aceea de a deschide istoria unei experiențe fundamentale de convertire şi înnoire, de a face din această istorie o «trecere» pascală către Împărăție. Iar răspunsul creştin la această criză devastatoare nu poate fi decât unul teologic şi liturgic"”. Prin urmare, datoria noastră este de a reafirma valoarea liturgică a lucrurilor şi a gesturilor simple care caracterizează viața de zi cu zi a omului modern, a creştinului modern, de a-l reaşeza teologic în gândirea patristică, astfel încât să descopere uşor sens duhovnicesc al realității şi existenței sale.

Unul dintre aceste lucruri extrem de simple al cărui sens liturgic trebuie recuperat şi redefinit este tăcerea. Într-o lume asaltată eminamente de cuvinte, prin reclame, prin muzică, prin producții care de care mai spectaculoase şi incendiare, nu numai că tăcerea a fost total abolită, dar chiar şi cuvintele în sine şi-au pierdut sacralitatea şi parcă s-au golit de sens şi nu mai au putere. Aceasta tristă constatare referitor la cuvinte, poate şi din cauza faptului că avându-le „totdeauna la îndemână şi folosindu-le atât de frecvent, le considerăm astăzi ca făcând parte din rutină. Deseori vorbim fără a gândi în prealabil şi fără a fi conştienți de impactul cuvintelor noastre" .

Această recuperare în tandem ,cuvânt-tăcere” are un negrăit impact pentru om, creat să realizeze prin proprie experiență adevărul

\footnotetext{
${ }^{2}$ Sorin Emanuel Bugner, Viața intimă a omului şi provocările postmoderniste asupra acesteia, Alba-Iulia, Edit. Reîntregirea, 2009, p. 195-232.

${ }^{3}$ Pr. Ioan Bizău, Viața în Hristos şi maladia secularizării, Cluj-Napoca, Edit. Patmos, 2002, p. 191.

${ }^{4}$ Hal Urban, Puterea cuvintelor: cum poți obține rezultate majore folosind cuvintele potrivite, trad. Renata Nicolescu, Bucureşti, Edit. Almatea, p. 12
} 
lucrurilor cu care vine în contact. Iar, la o analiză atentă, creştinul contemporan poate uşor să ajungă la o realitate prezentată de către Părintele George Remete în cartea Sfinției Sale Cunoaşterea prin tăcere, conform căreia ,atât sub raport existențial, cât şi artistic, filosofic şi teologic, cuvântul totdeauna limitează ... neavând acces în abisurile cunoaşterii şi în infinitul existenței ... ori împărtăşirea ființială este mai mult decât cuvântul”, . Şi, mergând mai departe ,în raportul ființial dintre cuvânt şi tăcere, prima idee sau impresie este aceea că tăcerea reprezintă golul, iar cuvântul plinul. Impresia este grăbită şi înşelătoare. Experiența ne arată că de multe ori cuvintele pot fi goale, iar tăcerile pot fi nu numai pline, ci chiar depăşind cuvintele cele mai pline" ${ }^{\text {. }}$. Iar în raport cu ființa, spune acelaşi Părinte, ,verbul o semnalează, dar tăcerea o aprofundează. Tăcerea o pătrunde, constituind singura condiție demnă de misterul, inefabilul şi sublimul ființei”?

Lămuriți astfel de aceste aserțiuni, transferăm conceptul deja plin de sens al sintagmei tăcere în spaţiu pur liturgic şi suntem preocupați de schimbarea de sens a lucrurilor. De unde această forță, acest impact al tăcerii, într-un cult împrumutat dintr-un cadru eminamente vocal, cum a fost cel iudaic ${ }^{8}$, într-un spațiu delimitat şi definit eminamente de cuvinte, consecință binecuvântată a înomenirii Logosului?

Ca răspuns, oferim 2 împrejurări care au putut genera în momentul formării creştinismului schimbarea raporturilor de forțe dintre cuvânt şi tăcere.

${ }^{5}$ George Remete, Cunoaşterea prin tăcere, ed. a III-a revizuită, Alba-Iulia, Edit. Reîntregirea, 2011, p. 9.

${ }^{6}$ Ibidem, p.10.

${ }^{7}$ Ibidem, p. 14.

${ }^{8}$ Alexander Schmemann, Introducere în Teologia liturgică, trad. ierom. Vasile Bârzu, Bucureşti, Edit. Sophia, 2002, p. 99; Preot Petre Vintilescu, Istoria Liturghiei în primele trei veacuri, Bucureşti, Edit. Nemira, 2001, p. 22. 
1. În sprijinul primului argument, marele liturgist, Părintele Robert Taft, în lucrarea Dincolo de Orient şi Occident, ne spune că ,ceea ce se observă că se întâmplă în perioada de unire a riturilor este o împlinire a structurii de bază, comună, a Euharistiei în ceea ce eu am numit «punctele ei slabe», adică cele trei puncte de «acțiune fără cuvinte» a structurii primare: 1 . intrarea în biserică; 2. sărutarea păcii şi transferarea darurilor, şi 3. frângerea, împărtăşirea şi ritualul de concediere. Ce ar putea fi mai natural să dezvolți ceremonialul acestor acțiuni, incluzând cântece şi adăugând rugăciuni potrivite? Aceasta, deoarece unul dintre cele mai obişnuite fenomene în dezvoltarea liturgică imediată este refuzul de a lăsa un gest să vorbească singur" ${ }^{\prime} . \mathrm{Cu}$ alte cuvinte, aici observăm clar cum Părintele Robert, pe lângă faptul că indică cu acrivie scheletul liturgic al ritualului „frângerii pâinii”, adevereşte faptul că întreaga atenție se concentra pe actele instituirii de către Hristos la Cina cea de Taină, apanajul solemnității adăugându-se ulterior în decursul veacurilor, prin evlavia creștinilor ${ }^{10}$. Ori, totul se desfăşura într-o tăcere cultică, într-o sobrietate impusă atât de contextul istoric, cât mai ales de simplitatea gesturilor-nucleu.

2. În susținerea celui de-al doilea argument, plecăm de la exemplul Mitropolitului Kalistos Ware care în lucrarea Rugăciune şi tăcere în spiritualitatea ortodoxă, face o inspirată analogie între o apoftegmă patericală şi Rugăciunea lui Iisus. Astfel, după ce ne relatează cum avva Ammona îi răspunde unui bătrân care i-a cerut sfat, că, dacă vrea să se mântuiască, să stea în

\footnotetext{
${ }^{9}$ Robert F. Taft, Oltre l'oriente e l'occidente. Per una tradizione liturgica viva, Roma, Edit. Lipa, 1999, p. 220.

${ }^{10}$ Idem, Ritul bizantin, trad. Dumitru Vanca şi Alin Mehes, Alba-Iulia, Edit. Reîntregirea, 2008, pp. 26-28.
} 
chilia lui, să mănânce puțin şi să aibă întotdeauna cuvântul vameşului în inima lui, conchide: „cuvintele vameşului - Miluieşte-mă, Dumnezeule, pe mine, păcătosul! (Luca 18, 13), sunt foarte aproape de formula Rugăciunii lui Iisus, care apare din secolul al VI-lea, mai ales la Varsanufie din Gaza († spre 540) şi în viața avvei Filimon"11. Aşa şi noi, dacă preluăm analogia ca metodă de investigație şi o raportăm la evlavia creştinilor din Biserica primară şi la dorinţa lor de a-şi însuşi cu fidelitate gesturile pe care le-a făcut Hristos sau care I-au prilejuit bucurie, putem apropia tăcerea ca formă cultică de manifestare, de atitudine penitențială, dar şi de manifestare deplină a omului în fața taina „frângerii pâinii", de gestul profund al prostituatei din referatul lucanic, ce în casa fariseului Simon, vine abia simțită prin spatele lui Hristos, I se aşază la picioare, plânge cu amar, udă picioarele Mântuitorului cu lacrimi şi apoi I le şterge cu părul capului ei, ca mai apoi să le înmiresmeze cu arome de nard. Totul, în cea mai mare tăcere din partea ei, şi, printr-un limbaj nerostit al gesturilor îşi manifestă profunda pocăință şi cere iertare. Astfel, aşa cum vameşul generează în tradiția creştină, prin cuvintele sale de umilință, Rugăciunea isihastă, nu se poate asocia, cel puțin, apropierea în tăcere a acestei femei păcătoase de Hristos, cu raportarea prin tăcerea a creştinilor din perioada de început a Bisericii la Taina Euharistiei ?

\footnotetext{
${ }^{11}$ Prea Sfințitul Kallistos Ware, Rugăciune şi tăcere în spiritualitatea ortodoxă, trad. Gabriela Moldoveanu şi Maica Siluana Vlad, Bucureşti, Edit. Christiana, 2003 , p. 74.
} 


\section{Tăcerea ca act liturgic în cultul ortodox}

În Biserica Ortodoxă, Liturghia Darurilor mai înainte sfințite se evidențiază prin câteva particularități care dau sens perioadei tipiconale în care se săvârşeşte, şi anume Perioada Triodului ${ }^{12}$. Această Liturghie este văzută de către liturgiştii contemporani mai mult ca o Slujbă de împărtăşire precedată de Vecernie ${ }^{13}$ sau ca o Vecernie a împărtăşirii cu Darurile Înaintesfințite ${ }^{14}$. Denumirile respective au ca suport patristic cel mai vechi Evchologhion bizantin, Barberini graecus 336, potrivit căruia rânduiala de seară a împărtăşirii nu este numită Liturghie, ci este redată prin „Slujba luminii de seară pentru Darurile înainte sfințite" ${ }^{15}$, fiind astfel alcătuită din unirea primei părți a Vecerniei cu a doua parte a Sfintei Liturghii, cu Liturghia euharistică.

Chiar dacă aceste recente reconsiderări de ordin lingvistic ne conturează şi mai bine caracterul ei eminamente vesperal, totuşi nu prin aceasta se evidențiază ca unică această amplă rânduială. Spuneam puțin mai sus că ea concentrează, sau mai bine spus, dă sens întregii perioade liturgice pe care o străbate, a Triodului, ori, aici este vorba de latura ei eminamente penitențială, Părintele Schmemann numind-o ,punctul culminant al rugăciunii din Postul Mare" ${ }^{\prime 6}$. Acest interval de timp, în accepțiunea Părintelui Makarios Simonopetritul, „este o perioadă de întristare şi străpungere a

${ }^{12}$ Perioada Triodului însumează cultul liturgic dintre Duminica Vameşului şi Fariseului şi Sâmbăta Mare.

${ }^{13}$ Alexander Schmemann, Postul Mare. Paşi spre Inviere, trad. pr. dr. Vasile Gavrilă, Bucureşti, Edit. Sophia, 2013, p. 94-95.

${ }^{14}$ Ieromonah Petru Pruteanu, Liturghia ortodoxă: istorie şi actualitate, ed. a IIa, revizuită şi completată, Bucureşti, Edit. Sophia, 2013, p. 180.

${ }^{15}$ Diacon Ioan I. Ică jr., Canonul Ortodoxiei, vol. I, Sibiu, Edit. Deisis, 2008, p. 928.

${ }^{16}$ Alexander Schmemann, Postul Mare..., p. 99. 
inimii" ${ }^{17}$, iar Liturghia Darurilor deține câteva elemente definitorii în acest sens.

Ca parte de început a ei, în cadrul Vecerniei, avem citiri din Psalmi ${ }^{18}$ împărțiți în trei stări, apoi avem ritualul luminii, urmat imediat de intonarea din nou a câtorva versete din psalmi, cu cădire în jurul Sfintei Mese, avem citiri din paremii, ecfonise speciale, un Heruvic special, o Rugăciune a Amvonului specifică şi un otpust aparte $^{19}$, însă ceea ce o arată ca fiind unică în manifestarea ei tipiconală, sunt tocmai două momente de tăcere liturgică pe care aceasta le cuprinde în desfăşurare, şi anume, primul, în timpul stării a treia $^{20}$, deci a Vecerniei, când Sfântul Agneț ${ }^{21}$ este transferat de pe Sfânta Masă a Altarului la Proscomidiar, iar al doilea, în timpul Heruvicului ${ }^{22}$, când Sfântul Agneț este purtat în procesiune de la Proscomidiar înapoi pe Sfânta Masă, de data aceasta, după cum se şi poate observa, în partea a doua, partea Liturghiei euharistice.

Deosebirea dintre cele două procesiuni constă în primul rând că prima se desfăşoară strict în perimetrul Sfântului Altar, dvera sau perdeaua Uşilor împărăteşti fiind închisă, deci credincioşii nu pot vedea această mutare rituală, dar sunt atenționați de începutul şi sfârşitul ei printr-un sunet de clopoțel, iar a doua are ca spațiu de acțiune Sfântul Altar şi soleea din fața iconostasului, deci se trece prin fața credincioşilor. Dvera Uşilor împărăteşti fiind deschisă, se deschide şi uşa diaconească din partea de miazănoapte, iar protosul, adică preotul oficiant care poartă Sfântul Disc ce are acoperit cu

${ }^{17}$ Ieromonah Makarios Simonopetritul, Triodul explicat. Mistagogia timpului liturgic, ed. a II-a, trad. diac. Ioan I. Ică jr. Sibiu, Edit. Deisis, 2003, p. 212.

${ }_{18}^{18}$ Ştim ca Psaltirea este prin excelenţă o carte penitențială.

19 Preot Prof. Dr. Ene Branişte, Liturgica specială pentru facultățile de teologie, ed. a IV-a, Bucureşti, Edit. Lumea Credinței, 2005, pp. 269-273.

${ }^{20}$ Liturghier, Bucureşti, Edit. IBMO, 2012, p. 297

${ }^{21}$ Agnețul (lat. agnus, „miel”) este bucata de pâine dospită, în formă cubică, tăiată de către preot la proscomidie din prescura principală, şi care se va preface, în cadrul Sfintei Liturghii, în Trupul lui Hristos. Sfântul Agneț este deci propriu-zis pâinea de împărtăşanie, şi doar el se preface în Trupul lui Hristos la epicleză.

${ }^{22}$ Liturghier..., p. 315. 
steluţă şi procovățul mic Sfântul Agneț, trece prin uşile diaconeşti şi vine pe centrul soleii, aşadar în faţa credincioşilor.

Dacă la primul moment de tăcere, credincioşii din Biserică nu au acces vizual, la cel de-al doilea moment, ei constituie scopul procesiunii, adică, protosul ieşind pe solee cu Sfântul Disc ținut cu mâna dreaptă la frunte, şi cu Sfântul Potir apropiat cu mâna stângă de piept, în momentul în care se opreşte pe centru soleii, se îndreaptă spre credincioşi şi îi binecuvintează în semnul Sfintei Cruci cu Sfântul Disc. După acest gest, își continuă drumul către Sfânta Masă pe care aşază Sfintele Daruri.

Se poate spune că cele două momente de tăcere din cele două etape distincte ale acestei Rânduieli de Împărtăşire corespund celor două Testamente. Adică, prima mutare din timpul Vecerniei, are loc la starea a treia, doar în Sfântul Altar, cu perdeaua închisă, şi ar corespunde Vechiului Testament, vecernia în sine închipuind perioada veterotestamentară a pocăinței lui Adam şi a aşteptării Naşterii lui Mesia, conform promisiunii lui Dumnezeu şi profețiilor $^{23}$. De asemenea, preînchipuie Cuvântul Care lucra încă de pe atunci în istorie, chiar dacă în chip nevăzut, pentru conducerea poporului ales spre „plinirea vremii” (Gal. 4, 4) Întrupării Sale. A doua procesiune, în schimb, are loc în partea a doua a Rânduielii, adică în Liturghia euharistică, şi ni-L arată pe Hristos venit în lume, binecuvântând şi mântuind neamul omenesc, pe care şi-L asumă, şi, împreună cu acesta, intră întru slava Tatălui (cf. In. 12, 32).

Totul se petrece în cea mai profundă tăcere, aşa cum prevăd indicațiile tipiconale din Liturghier, nerostindu-se nimic, nici măcar ceva şoptit de către protos, la momentul binecuvântării. În ambele momente, credincioşii ,îş̧i pleacă genunchii cu mare umilință ... în adâncă tăcere" ${ }^{24}$, iar Părintele Petru Pruteanu spune că la ruşi, îngenuncherea impuse obligatoriu şi punerea frunții la pământ, „,pentru a arăta măreția tainei ce nu poate fi văzută sau cuprinsă, ${ }^{\text {, }}$.

\footnotetext{
${ }^{23}$ Preot Prof. Dr. Ene Branişte, Liturgica specială..., p. 49.

${ }^{24}$ A se vedea indicațiile tipiconale din Liturghier..., p. 297 şi 315.

${ }^{25}$ Ieromonah Petru Pruteanu, op. cit., nota 5, p. 197.
} 
Despre acelaşi mod de întâmpinare a Sfântului Agneț aflat în procesiune, şi Părintele Makarios Simonopetritul depune aceeaşi mărturie: „Procesiunea se face în tăcere absolută, toată asistența fiind prosternată cu fața la pământ" ${ }^{\prime 26}$.

Pentru a înțelege şi mai bine sensul acestor acte liturgice învăluite în taina nerostită a tăcerii, în cele ce urmează vom expune lămuririle care s-au fixat în scris de-a lungul tradiției patristice în Biserica noastră. În acest sens, Tipicul cel mare al Sfântului Sava cel Sfinţit, prevede în legătură cu această prosternare din cadrul Heruvicului, că noi, ,căzând în genunchi, ne închinăm cuvios Domnului Hristos Dumnezeu, şi facem Celui ce este în Sfintele Taine închinăciune, deoarece Darurile sunt înainte Sfințite"27. Aici, Sfântul Sava vrea să ne îndemne să oferim aceeaşi cinstire Sfântului Agneț, şi în speță, Sfintei Împărtăşanii, ca Persoanei lui Hristos Însuşi, intre cele două neexistând nicio deosebire ${ }^{28}$.

Tot despre acest moment al procesiunii din timpul Heruvicului la Liturghia Darurilor, numit în termeni liturgici „Vododul Mare”, ca moment al Aducerii Darurilor, Părintele Alexander Schmemenn spune că el diferă esențial față de acelaşi moment de la o Liturghie deplină ${ }^{29}$. Astfel, la Liturghia deplină avem însumarea întregii Biserici în Jertfa lui Hristos, care se va actualiza prin epicleză, iar la Liturghia Darurilor, procesiunea „nu mai este punere înainte, nici jertfă, nici Euharistie, nici sfințire, ci taina prezenței lui Hristos în Biserică este revelată şi manifestată!"’30. Acelaşi lucru îl mărturiseşte

\footnotetext{
${ }^{26}$ Ieromonah Makarios Simonopetritul, op. cit., p. 223.

${ }^{27}$ Tipicul cel mare al Sfântului Sava cel Sfințit, p. 498; a se consulta on line la adresa

ftp://ftp.logos.md/Biblioteca/_Colectie_RO/Tipicul\%20cel\%20Mare\%20al\%20 Sfantului\%20Sava.pdf

${ }^{28}$ A se vedea aici şi Preotul Profesor Dumitru Stăniloae, Teologia Dogmatică Ortodoxă, vol. III, Bucureşti, Edit. IBMBOR, 2003, p. 96.

${ }^{29}$ Prin „Liturghie deplină” înțelegem fie Liturghia Sfântului Ioan Gură de Aur , fie Liturghia Sfântului Vasile cel Mare, care, ambele, au Rugăciunea de prefacere a Pâinii şi Vinului în Trupul şi Sângele lui Hristos, numită epicleză.

${ }^{30}$ Alexander Schmemann, Postul Mare..., pp. 102-103.
} 
şi Sfântul Simeon al Tesalonicului când motivează îngenuncherea credincioşilor prin faptul că „Ceea ce este pe Disc este Preasfântul Său Trup, împreună cu Dumnezeiescul Sânge" ${ }^{\text {31 }}$.

Faptul că Sfântul Disc ce conține Sfântul Agneț, în timpul procesiunii prin fața credincioşilor, este acoperit cu un suport metalic numit steluță peste care se aşază procovățul mic, un acoperământ în formă pătrată sau de cruce, are o însemnătate aparte în interpretarea mistică. Astfel, Sfântul Teodor Studitul dă următoarea indicație: „dacă la celelalte jertfe, jertfa e săvârşită în chip neacoperit şi neîndoielnic, aici ea se face în chip umbrit şi cu plâns. Căci în toate, această celebrare este mai tainică" ${ }^{\prime 2}$. Acest lucru, deoarece, în accepțiunea aceluiaşi Părinte Makarios, intrarea se face sub semnul căinţei, deoarece „anticipează «tainic» a Doua Venire”33. Acelaşi Sfânt Părinte, ne îndeamnă ca, în acest moment de tăcere adâncă din timpul procesiunii Vohodului Mare de la Liturghia Darurilor, „,datori suntem [din cauza păcatelor noastre n.n.] a cădea la pământ înaintea lui cu osârdie, a cere iertare greşelilor, a pomeni pe toți credincioşii în vremea vohodului, când Îl poartă pe El preotul pe cap, căci Tainele sunt săvârşite şi este Însuşi Trupul şi Sângele lui Hristos" ${ }^{\text {"34 }}$.

În toată această expunere, Părintele André Scrima ne avertizează că există şi un risc major, şi anume ,ca prin didacticismul nostru liturgic, să transformăm pe credincioşi în simpli spectatori. Privirea obiectivă de-semnifică simbolul. Riturile şi simbolurile instituie omul: ele nu sunt operante decât cu condiția să fie asumate

31 Sfântul Simeon, Arhiepiscopul Tesalonicului, Tratat asupra tuturor dogmelor credinței noastre ortodoxe, după principii puse de Domnul nostru Iisus Hristos şi urmaşii Săi, vol. II, trad. Protos. Grichentie Natu, Suceava, Edit. Arhiepiscopiei Sucevei şi Rădăuţilor, 2003, p. 107.

${ }^{32}$ Sfântul Teodor Studitul, Explicația dumnezeieştii Liturghii a Darurilor mai inainte sfințite, PG 99, 1688B, apud Ieromonah Makarios Simonopetritul, op. cit., p. 223.

${ }^{33}$ Ibidem.

${ }^{34}$ Sfântul Simeon, Arhiepiscopul Tesalonicului, op. cit., p. 235. 
de credincioşi. Adevăratele semne simbolice operează o transpoziție de sens, o trecere (plan pascal)"35.

Putem evita acest pericol prin explicarea mai în amănunt a ceea ce se întâmplă în sufletul nostru în timpul liniştirii, al isihiei, al reculegerii, al tăcerii, ca astfel, credincioşi să înțeleagă procesul duhovnicesc la care sunt chemați prin tăcerea liturgică, să şi-l asume şi să devină lucrători ai roadelor pocăinței (cf. Lc. 3, 8). În acest sens, Sfântul Ioan Gură de Aur ne îndeamnă ca prin tăcere, să coborâm cu mintea în sufletul nostru şi acolo, fiind de faţă doar noi şi Hristos, săI mărturisim tainic toate păcatele noastre şi astfel, prin pocăinţă primim iertare şi ne putem apropia de Potir ${ }^{36}$. În alt loc, Sfântul Ioan Scărarul, cu privire la roadele tăcerii, ne sfătuieşte astfel: „Prietenul tăcerii se apropie de Dumnezeu şi, vorbind cu El, fără să ştie cum, e luminat de Dumnezeu"37. Iar despre cunoaşterea de sine ca rod al tăcerii şi concentrării lăuntrice, Părintele Dumitru Stăniloae ne spune că ,închiderea simţurilor duce la concentrarea minții într-o meditație întoarsă asupra ei înseşi”’38.

\section{Exercițiul adorării în practica romano-catolică}

Tradiția liturgică apuseană redescoperă odată cu Conciliul II Vatican $^{39}$ „tăcerea sacră”, care de atunci, va face parte integrantă

35 André Scrima, Biserica liturgică, trad. Anca Manolescu, Bucureşti, Edit. Humanitas, 2005, p. 317.

${ }^{36}$ Sfântul Ioan Gură de Aur, Omilii la pocăință, trad. pr. prof. Dumitru Fecioru, Bucureşti, Edit. IBMBOR, 1998, p. 49.

${ }^{37}$ Sfântul Ioan Scărarul, Scara dumnezeiescului urcuş, în «Filocalia», nr. 9, trad. Pr. Prof. Dr. Dumitru Stăniloae, Bucureşti, Edit. IBMO, p. 242.

${ }^{38}$ Preotul Profesor Dumitru Stăniloae, Ascetica şi mistica Bisericii Ortodoxe, Bucureşti, Edit. IBMBOR, 2002, p. 172.

${ }^{39}$ Al Doilea Conciliu Vatican a abordat relațiile dintre Biserica RomanoCatolică şi lumea modernă. Aceasta a fost al 21-lea conciliu ecumenic din istoria Bisericii, recunoscut ca atare doar de Biserica apuseană, şi al doilea conciliu care a avut loc la Bazilica Sfântul Petru din Vatican. A fost deschis 
din aproape toate oficiile cultice. În Documentul Sacrosantum concilium: Constituția despre sfânta liturghie, articolul 30 prevede: „Pentru a promova participarea activă, se va pune accent pe aclamațiile poporului, pe răspunsuri, cântarea psalmilor, antifoane, cântece, precum şi pe acțiunile, gesturile şi atitudinile corporale. Se va respecta, de asemenea, la timpul cuvenit, tăcerea sacră ${ }^{, 40}$. Aşa cum se poate observa, tăcerea, ca parte a celebrării, vine să motiveze „participarea activă” a credincioşilor, astfel încât aceştia „,ă se intersecteze intim cu taina care se celebrează ${ }^{, 41}$. În continuare, această tăcere este văzută „nu ca un element absolut şi de neînlocuit, cu caracter magic, necesar şi semnificativ, ci o tăcere a participării, astfel o condiție spirituală pentru înțelegerea şi primirea misterului celebrării” ${ }^{, 2}$.

În susținerea celor spuse, teologul catolic Annibale Bugnini, lămureşte: „nu vrem spectatori inerți şi muți, ci participanți activi conştienți şi rugători, care să conştientizeze «trăirea» tainei prin rugăciune, prin cântare, prin concentrare, prin tăcere, care toate împreună să ateste adorarea. Tăcerea nu indică o muțenie spirituală, ci un mişcător moment al harului, în timpul căruia creatura tace, dar Duhul vorbeşte" ${ }^{\text {43 }}$.

Din cele prezentate în acest segment, uşor ne putem da seama că dimensiune tăcerii liturgice din tradiția romano-catolică diferă substanțial față de încărcătura penitențială cu care o aflăm în Liturghia Darurilor mai înainte sfințite. Teologia apuseană se axează mai mult pe îmbogăţirea şi purificarea spirituală a sufletului prin actul în sune al exercițiului tăcerii sacre, decât pe coborârea în abisurile ființei şi cunoaşterea stării de păcat, aşa cum se întâmplă în tradiția răsăriteană.

de Papa Ioan Al XXIII-lea la 11 octombrie 1962 şi închis în timpul pontificatului papei Paul al VI-lea la 8 decembrie 1965.

${ }^{40} \mathrm{http}$ ://www.magisteriu.ro/sacrosanctum-concilium-1963/

${ }^{41}$ Dizionari San Paolo, Torino, Edit, San Paolo, 2001, p. 1869.

${ }^{42}$ Ibidem.

${ }^{43}$ Annibale Bugnini, Tibi silentium laus, in Not 11, 1975, 282, apud Dizionari San Paolo, Torino, Edit, San Paolo, 2001, p. 1872. 
În acest sens, teologul Joseph Ratzinger, ajuns Papa Benedict al XVI-lea, spunea într-una dintre meditaţiile sale: „Capacitatea de interioritate, o deschidere mai mare a spiritului, un stil de viață care să ştie să se sustragă de la ceea ce este zgomotos şi invadent, trebuie să ne apară din nou ca ținte care trebuie numărate printre prioritățile noastre. În Paul găsim exortația de a ne întări în omul interior (Ef. 3,16). Să fim cinstiți: astăzi există o hipertrofie a omului exterior şi o slăbire îngrijorătoare a energiei sale interioare" 44 .

Subliniind diferența dintre cele două atitudini, Părintele Alexander Schmemann menționează că procesiunea din cadrul Vohodului Mare al Liturghiei Darurilor nu are scop adorativ al acestora de către credincioşi, ci acestea se transferă de la Proscomidiar pe Sfânta Masă ,în vederea Împărtăşirii ${ }^{45}$ ". Ori noi, chiar şi prin obiceiul păstrării în chivotul de pe Sfânta Masă a Împărtăşaniei în formă uscată pentru cuminecarea grabnică a bolnavilor, noi avem conştiința unei permanente prezențe a Darurilor, şi nu absența adorării lor ${ }^{\text {"46 }}$. Ori manifestarea adorativă în Biserica Apusului s-a concretizat prin procesiuni cu Sfântul Sânge sau cu Ostia.

Şi ca să concluzionăm cele prezentate mai sus, tăcerea liturgică primeşte notă adorativă care „e o tăcere constructivă, e coeficientul fundamental pentru edificarea şi formarea comunităţii euharistice slujitoare" ${ }^{, 7}$.

\section{Mesajul Sâmbetei Mari pentru actuala criză spirituală}

În paralel cu precizarea tipiconală a celor două momente de tăcere din cadrul Liturghiei Darurilor mai înainte sfințite, în alcătuirea Triodului aflăm în Sâmbăta Mare un tropar pe glasul 5 ce

\footnotetext{
${ }^{44}$ Joseph Ratzinger, Fede, Veritŕ, Tolleranza. Il cristianesimo e le religioni del mondo, Siena, Edit. Cantagalli, 2003, pag. 167.

${ }^{45}$ Alexander Schmemann, Postul Mare..., p. 103.

${ }^{46}$ Ibidem.

${ }^{47}$ Dizionari San Paolo..., p. 1872.
} 
înlocuieşte Heruvicul Liturghiei Sfântului Vasile cel Mare, şi care are următorul conținut: „Să tacă tot trupul omenesc şi să stea cu frică şi cu cutremur, şi nimic pământesc întru sine să nu gândească; că Împăratul împăraților şi Domnul domnilor merge să Se junghie şi să Se dea de mâncare credincioşilor. Şi merg înaintea Lui cetele îngereşti, cu toată căpetenia şi puterea, Heruvimii cei cu ochi mulți, şi Serafimii cei cu câte şase aripi, fețele acoperindu-şi şi cântând cântarea: Aliluia, Aliluia, Aliluia" ${ }^{\circ 8}$.

Dintr-o primă citire, uşor ne putem da seama de similitudinea dintre acest tropar şi indicaţiile tipiconale de la Liturghia darurilor, căci, în ambele cazuri, indicațiile secvențiale sunt aceleaşi: suntem îndemnați la tăcere desăvârşită, nici măcar cu gândul să nu gândim ceva străin de cele ce se petrec înaintea ochilor noştri, pentru că urmează sa-L vedem pe Hristos cum vine spre a Se da ca mâncare şi băutură celor ce Îl vor primi cu credință. Astfel, Îl vedem pe Hristos în stare de jertfire, de dragul neamului omenesc, ca omul să aibă viață, şi încă o viață îmbelşugată (cf. In. 10, 10).

Cugetând pe marginea celor precizate în acest tropar, Sfântul Isaac Sirul ne lămureşte: „Aici trebuie să înceteze toată gura şi limba şi inima, vistiernică a gândurilor, şi mintea, cârmuitoare a simțurilor, şi cugetarea, pasăre repede zburătoare şi plină de îndrăznire, şi orice meşteşug al lor. Cei ce cer, să rămână aici! Pentru că e de faţă Stăpânul" "49. Astfel, cele spuse de către Sfântul Isaac, ne îndreptățesc să conchidem faptul că prin însăşi poziționarea lui la finalul perioadei Triodului, acest tropar are față de momentele tăcerii liturgice penitențiale un crescendo. Astfel, dacă la Liturghia Darurilor pe tot parcursul Postului Mare am fost îndemnați în mod tainic la prosternare, la străpungerea inimii, la ajunare desăvârşită, la spovedanie, iată acum, în Sâmbăta Mare suntem chemați, deşi aparent în aceeaşi stare de încremenire ființială a unei tăceri atotcuprinzătoare, dar de data aceasta la Nunta

${ }^{48}$ Triod, Bucureşti, Edit. IBMO, p. 691.

${ }^{49}$ Apud Prea Sfințitul Kallistos Ware, Rugăciune şi tăcere..., p. 83-84. 
Dumnezeului nostru, pentru că El, vine în chip vădit, nu ascuns, şi ne cheamă la Cină, ni Se oferă întru-totul spre hrană. Ori întregul alai însoțitor al Heruvimilor şi Serafimilor, cu abilitățile lor marcate la nivel textual prin mulțime de ochi şi de aripi, cu cântarea lor întreită, nu fac altceva decât să creeze, atât la nivel imaginativ, cât aproape perceptibil, grandoarea alaiului imperial ce înconjoară Euharistia.

În acest sens, acum tăcerea liturgică primeşte o altă conotație: suntem chemați să ne umplem de dumnezeire, după ce, un Post întreg am exersat pocăinţa şi străpungerea inimii. Astfel, Mitropolitul Kalistos Ware spune: ,cel ce tace, caută să se umple de sentimentul şi de plinătatea Prezenței dumnezeieşti ... tăcerea nu mai este un vid negativ, o pauză între două cuvinte, un scurt repaus înainte de a relua vorbirea, ci cu totul pozitivă: o atitudine vie de atenţie, de vigilență şil înainte de toate, de ascultare. Isihastul este, prin excelență, cel ce ascultă, cel ce se deschide prezenței Celuilalt, Care exclamă: Opriți-vă şi cunoaşteți că Eu sunt Dumnezeu! (Psalmi 45, 10)"50. În această apropiere dintre on şi Dumnezeu, spune Mitropolitul Ardealului, Înaltpreasfințitul Laurențiu, „nu materia, nici actele nu constituie Taina, misterul sacramental, ci întâlnirea în credință, a două subiecte în ambianța Bisericii. Dumnezeu şi omul se întâlnesc în şi prin prezența sacramentală a Dumnezeului-Om; întâlnirea aceasta este configuratoare şi prin Sfântul Duh în Biserica îndumnezeitoare" ${ }^{\text {"51 }}$.

În asentimentul celor spuse mai sus, Părintele Sofronie sintetizează toată lucrarea lăuntrică desfăşurată pe întregul parcurs al Postului Mare, astfel: „odată cu pocăinţa şi creşterea harului înăuntrul nostru, care îi urmează, realitatea Lumii Dumnezeieşti

${ }^{50}$ Ibidem, p. 81-82.

${ }^{51} \uparrow$ Dr. Laurențiu Streza, Mitropolitul Ardealului, Plinitu-S-a, Hristoase, Taina rânduielii Tale. Studii de teologie Liturgică, Sibiu, Edit. Adreiană, 2012, p. 152. 
predomină asupra lumii văzute" 52 , adică, încet, şi aproape în mod insesizabil devenim oameni lăuntrici, care ne înnoim zi de zi în Duhul Sfânt (cf. II Cor. 4, 16).

Astfel, pentru omul ancorat în postmodernitate, acest tropar al Sâmbetei Mari îi oferă este cheia rezolvării crizei spirituale: înțelegerea şi imitarea lui Hristos. El, ca şi Dumnezeu Creator al nostru, Se jertfeşte pe Sine ca noi să trăim; Se dă pe Sine de mâncare, ca omul să aibă viață, şi încă o viață îmbelşugată (cf. In. $10,10)$. Hristos aşa a considerat să scoată omenirea din robia morții: dăruindu-Se. La acest gest suprem de dăruire din partea lui Dumnezeu, lumea postmodernă este chemată ca prin tăcere şi Împărtăşire euharistică, să-şi repună în valoare prioritățile, cu alte cuvinte, să se repoziționeze față de tot ce e risipire, destrămare, vid. Iar pericolul unei prăbuşiri este iminent, după cum atenționează Sfântul Paisie Aghioritul, prin următoarele cuvinte: „Marea majoritate a lumii epocii noastre este instruită lumeşte şi aleargă cu o viteză lumească mare, dar fiindcă îi lipseşte frica de Dumnezeu, care este începutul înțelepciunii, îi lipseşte frâna, iar cu viteză, fără frână, sfârşeşte în prăpastie" ${ }^{53}$.

\section{În loc de concluzii}

Pentru o şi mai bună cunoaştere a folosului practicării „tăcerii liturgice" în cadrul Liturghiei Darurilor, ar fi de preferat, mai întâi, prezentarea sub formă de cateheze mistagogice a istoricului şi scopului acestei Liturghii penitențiale, ca toți participanții la aceasta să-i înțeleagă desfăşurarea criptică şi rostul fiecărei atitudini liturgice.

52 Arhimandritul Sofronie, Rugăciunea, experiența vieții veşnice, trad. diac. Ioan I. Ică jr., Sibiu, Edit. Deisis, 2001, p. 53.

${ }^{53}$ Cuviosul Paisie Aghioritul, Cuvinte duhovniceşti. Cu durere şi cu dragoste pentru omul contemporan, vol. I, trad. Ieroschim. Ştefan Nuțescu, Bucureşti, Edit. Evanghelismos, 2003, p. 21. 
Apoi, în al doilea rând, pentru o mai bună concentrare şi o inițiere în tăcerea isihastă, propunem metoda privegherii Cuviosului Gheorn Isihastul († 1959). Sintagma ,priveghere” nu are în accepțiunea Bătrânului înțelesul standard, adică de Rânduială de toată noaptea a ciclului de Vecernie, Utrenie şi Liturghie, ci, prin priveghere, Gheron Iosif îi indemna pe ucenicii săi să se retragă în tăcere desăvârşită, în chiliile lor, sau în peşteri, unde să înceapă să se liniştească, ca mai apoi să poată medita la Pătimirile lui Hristos, la Slava Lui, la chinurile iadului, la starea de păcătoşenie în care se află, ca astfel obținând starea de străpungere a inimii şi de liniştire a minții să înceapă să se concentreze pe pomenirea cât mai deasă Numelui lui Iisus, exercițiu ce le va atrage, treptat, harul Duhului Sfânt în inimă ${ }^{54}$.

Şi ca ultimă recomandare, propun conştientizarea, în primul rând, a ,tăcerii liturgice” pe care o practicăm, deşi puțin conştienți, în cadrul Liturghiei depline, când, imediat după rostirea rugăciunilor epiclezei, şi atâta timp cât la strană încă nu s-a terminat imnul „Pe Tine Te lăudăm..”, noi, clericii, ne prosternăm în fața Sfintei Mese, sau ne reculegem în picioare, şi ne rugăm în cugetul nostru şi în deplină tăcere lui Hristos Care tocmai a venit din nou să ni Se ofere spre mâncare. Şi ca o a doua etapă, impunerea a câteva secunde, pentru început, de tăcere pentru întreaga comunitate euharistică, asta, după ce în prealabil am făcut o catehizare în acest sens, ca şi poporul să perceapă bucuria prezenței tainice a lui Hristos pe Sfânta Masă, şi astfel, prin tăcere, să contemple şi să-şi descopere starea lăuntrică, ce nu este altceva decât haina de nuntă (Mt. 22, 11-12).

\footnotetext{
${ }^{54}$ Gheron Iosif, Mărturii din viața monahală, trad. Pr. Prof. Dr. Constantin Coman, Bucureşti, Edit. Bizantină, 1992, p. 163, p. 223, p. 336; Monahul Iosif Vatopedinul, Trăiri ale Dumnezeiescului Har, trad. Ierom. Agapie Corbu, Arad, Edit. Sf. Nectarie, 2008, p. 118; Arhim. Efrem Filoteitul, Starețul meu, Iosif Isihastul, trad. Ieroschim. Ştefan Nuțescu, Bucureşti, Edit. Evanghelismos, 2010 , p. 258 , p. 322 , p. 323.
} 


\section{Bibliografie:}

1. Arhimandritul Efrem Filoteitul, Starețul meu, Iosif Isihastul, trad. Ieroschim. Ştefan Nuțescu, Bucureşti, Edit. Evanghelismos, 2010.

2. Arhimandritul Sofronie, Rugăciunea, experiența vieții veşnice, trad. diac. Ioan I. Ică jr., Sibiu, Edit. Deisis.

3. Bizău, Pr. Ioan, Viața în Hristos şi maladia secularizării, ClujNapoca, Edit. Patmos, 2002.

4. Branişte, Preot Prof. Dr. Ene, Liturgica specială pentru facultățile de teologie, ed. a IV-a, Bucureşti, Ed it. Lumea Credinței, 2005.

5. Bugner, Sorin Emanuel, Viața intimă a omului şi provocările postmoderniste asupra acesteia, Alba-Iulia, Edit. Reîntregirea, 2009.

6. Bugnini, Annibale, Tibi silentium laus, in Not 11, 1975, 282.

7. Cuviosul Paisie Aghioritul, Cuvinte duhovniceşti. Cu durere şi cu dragoste pentru omul contemporan, vol. I, trad. Ieroschim. Ştefan Nuțescu, Bucureşti, Edit. Evanghelismos, 2003.

8. Gheron Iosif, Mărturii din viața monahală, trad. Pr. Prof. Dr. Constantin Coman, Bucureşti, Edit. Bizantină, 1992.

9. Ică jr., Diacon Ioan I., Canonul Ortodoxiei, vol. I, Sibiu, Edit. Deisis, 2008.

10. Ieromonah Makarios Simonopetritul, Triodul explicat. Mistagogia timpului liturgic, ed. a II-a, trad. diac. Ioan I. Ică jr. Sibiu, Edit. Deisis, 2003.

11. Monahul Iosif Vatopedinul, Trăiri ale Dumnezeiescului Har, trad. Ierom. Agapie Corbu, Arad, Edit. Sf. Nectarie, 2008.

12. Pruteanu, Ieromonah Petru, Liturghia ortodoxă: istorie şi actualitate, ed. a II-a, revizuită şi completată, Bucureşti, Edit. Sophia, 2013.

13. Ratzinger, Joseph, Fede, Veritŕ, Tolleranza. Il cristianesimo e le religioni del mondo, Siena, Edit. Cantagalli, 2003, pag. 167. ${ }^{1}$ Triod, Bucureşti, Edit. IBMO.

14. Remete, George, Cunoaşterea prin tăcere, ed. a III-a revizuită, AlbaIulia, Edit. Reîntregirea, 2011.

15. Schmemann, Alexander, Introducere în Teologia liturgică, trad. ierom. Vasile Bârzu, Bucureşti, Edit. Sophia, 2002.

16. Idem, Postul Mare. Paşi spre Inviere, trad. pr. dr. Vasile Gavrilă, Bucureşti, Edit. Sophia, 2013.

17. Idem, Pentru viața lumii. Sfintele Taine şi Ortodoxia, Bucureşti, Edit. Basilica, 2012.

18. Scrima, André, Biserica liturgică, trad. Anca Manolescu, Bucureşti, Edit. Humanitas, 2005. 
19. Sfântul Ioan Gură de Aur, Omilii la pocăință, trad. pr. prof. Dumitru Fecioru, Bucureşti, Edit. IBMBOR, 1998.

20. Sfântul Ioan Scărarul, Scara dumnezeiescului urcuş, în «Filocalia», nr. 9, trad. Pr. Prof. Dr. Dumitru Stăniloae, Bucureşti, Edit. IBMO.

21. Sfântul Simeon, Arhiepiscopul Tesalonicului, Tratat asupra tuturor dogmelor credinței noastre ortodoxe, după principii puse de Domnul nostru Iisus Hristos şi urmaşii Săi, vol. II, trad. Protos. Grichentie Natu, Suceava, Edit. Arhiepiscopiei Sucevei şi Rădăuților, 2003.

22. Stăniloae, Preotul Profesor Dumitru Ascetica şi mistica Bisericii Ortodoxe, Bucureşti, Edit. IBMBOR, 2002.

23. Idem, Teologia Dogmatică Ortodoxă, vol. III, Bucureşti, Edit. IBMBOR, 2003.

24. Streza, $\dagger$ Dr. Laurențiu, Mitropolitul Ardealului, Plinitu-S-a, Hristoase, Taina rânduielii Tale. Studii de teologie Liturgică, Sibiu, Edit. Adreiană, 2012.

25. Taft, Robert F., Ritul bizantin, trad. Dumitru Vanca şi Alin Mehes, Alba-Iulia, Edit. Reîntregirea, 2008.

26. Idem, Oltre l'oriente e l'occidente. Per una tradizione liturgica viva, Roma, Edit. Lipa, 1999.

27. Urban, Hal, Puterea cuvintelor: cum poți obține rezultate majore folosind cuvintele potrivite, trad. Renata Nicolescu, Bucureşti, Edit. Almatea.

28. Vintilescu, Preot Petre, Istoria Liturghiei în primele trei veacuri, Bucureşti, Edit. Nemira, 2001.

29. Ware, Prea Sfințitul Kallistos, Rugăciune şi tăcere în spiritualitatea ortodoxă, trad. Gabriela Moldoveanu şi Maica Siluana Vlad, Bucureşti, Edit. Christiana, 2003. 